\section{Herbicide Programs for Large Crabgrass and Goosegrass Control in Kentucky Bluegrass Turf}

\author{
B. Jack Johnson ${ }^{1}$ \\ Department of Crop and Soil Sciences, University of Georgia, Georgia \\ Station, Griffin, GA 30223-1797
}

Additional index words. Poa pratensis, turf injury, herbicide mixes, tank-mixes

\begin{abstract}
Low rates of preemergence herbicides were applied with postemergence herbicides as sequential applications or as tank-mixed applications for large crabgrass [Digitaria sanguinalis (L.) Scop.] and goosegrass [Eleusine indica (L.) Gaertn.] control in Kentucky bluegrass (Poa pratensis L.). In 1991, a higher percentage of large crabgrass control (83\%) was obtained in late August from sequential applications of oxadiazon at $2.2 \mathrm{~kg} \cdot \mathrm{ha}^{-1}$ applied in early March and followed by fenoxaprop at $0.20 \mathrm{~kg} \cdot \mathrm{ha}^{-1}$ in June than when oxadiazon $(62 \%)$ or fenoxaprop $(11 \%)$ was applied alone. During this period, sequential applications of oxadiazon at $2.2 \mathrm{~kg} \cdot \mathrm{ha}^{-1}$ and monosodium salt of MAA (MSMA) at $2.2 \mathrm{~kg} \cdot \mathrm{ha}^{-1}$ achieved $79 \%$ control of large crabgrass, while the control was at $\leq 46 \%$ when MSMA or fenoxaprop was applied to plots previously treated with pendimethalin at $1.7 \mathrm{~kg} \cdot \mathrm{ha}^{-1}$ or dithiopyr at $0.28 \mathrm{~kg} \cdot \mathrm{ha}^{-1}$. There was no advantage from sequential applications of preemergence and postemergence herbicides for large crabgrass control in 1992, when compared with postemergence herbicides applied alone. Large crabgrass control in late August was higher over 2 years from tank-mixes of pendimethalin at 1.7 $\mathrm{kg} \cdot \mathrm{a}^{-1}$ with fenoxaprop at $0.14 \mathrm{~kg}^{-h^{-1}}(\mathbf{8 0 \%})$ than when pendimethalin $(28 \%)$ or fenoxaprop (55\%) was applied alone at the same rates. The control was also higher from tank-mixes of pendimethalin at $1.7 \mathrm{~kg} \cdot \mathrm{ha}^{-1}$ with MSMA at $2.2 \mathrm{~kg} \cdot \mathrm{ha}{ }^{-1}(92 \%)$, when compared with MSMA (77\%) alone. The response was similar from tank-mixes of dithiopyr at $0.28 \mathrm{~kg} \cdot \mathrm{ha}^{-1}$ with fenoxaprop at $0.14 \mathrm{~kg} \cdot \mathrm{ha}^{-1}(98 \%)$ or with MSMA at 2.2

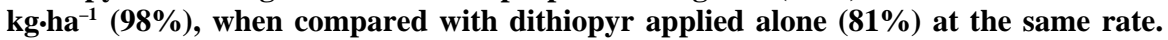
Quinclorac applied alone at $0.84 \mathrm{~kg} \cdot \mathrm{ka}^{-1}$ controlled large crabgrass as effectively as when applied to plots previously treated with preemergence herbicides or when applied tankmixed with preemergence herbicides. None of the preemergence herbicides applied at low rates with postemergence herbicides (fenoxaprop, MSMA, or quinclorac) controlled goosegrass. Chemical names used: $S, S$-dimethyl 2-(difluoromethyl)-4-(2-methylpropyl)6-(trifluoromethyl)-3,5-pyridinedicarbothioate (dithiopyr); ( \pm )-2-[4-[(6-chloro-2benzoxazolyl)oxy]-phenoxy]propanoic acid (fenoxaprop); 3-[2,4-dichloro-5-(1methylethoxy)-phenyl]-5-(1,1-dimethylethyl)-1,3,4-oxadiazol-2-(3H)-one (oxadiazon); $N$ (1-ethylpropyl)-3,4-dimethyl-2,6-dinitrobenzen-amine (pendimethalin); and 3,7-dichloro8-quinoline-carboxylic acid (quinclorac).
\end{abstract}

To maintain a high-quality turfgrass, herbicides are necessary for weed control in the overall management program. Crabgrass and goosegrass are chronic problem weeds; however, they can be effectively controlled with preemergence (Dernoeden and Davis, 1988; Johnson and Murphy, 1993) and postemergence (Chism and Bingham, 1991; Johnson, $1975,1980)$ herbicides. However, it is important that these herbicides be applied at the lowest effective rates whenever possible to ensure minimal environmental impact

Received for publication 11 June 1993. Accepted for publication 29 Jan. 1994. Supported by state and Hatch Act funds allocated to the Georgia Agricultural Experiment Stations. I thank L. Henderson, Butternut Creek Golf Course, Blairsville, and J. Davis, Station Statistician, for their cooperation and W. Olson, M. Gilmer, and T. Dinkins for their technical assistance in this study. The cost of publishing this paper was defrayed in part by the payment of page charges. Under postal regulations, this paper therefore must be hereby marked advertisement solely to indicate this fact.

${ }^{1}$ Professor. and adhere to best management strategies. Green (1991) concluded that the best method to reduce herbicide rates and maintain optimum weed control was by tank-mixing herbicides. Researchers in New York (Rossi et al., 1988) reported that smooth [D. ischaemam (Schreb. 'ex. Schweig') ex. Mubl.] and large crabgrass control was better 12 weeks after treatment (WAT) with tank-mixes of the preemergence herbicide pendimethalin at 1.7 $\mathrm{kg} \cdot \mathrm{ha}^{-1}$ with the postemergence herbicide fenoxaprop at $0.14 \mathrm{~kg} \cdot \mathrm{ha}^{-1}$ than when either was applied alone at the same rates. Combinations of herbicides at lower rates have not always performed effectively. Tank-mixed pendimethalin at $1.12 \mathrm{~kg} \cdot \mathrm{ha}^{-1}$ with fenoxaprop at $0.14 \mathrm{~kg} \cdot \mathrm{ha}^{-1}$ controlled smooth crabgrass 94\% in Pennsylvania (Watschke and Hamilton, 1990), but the control of smooth and large crabgrass was lower in New York (50\%) (Rossi et al., 1988). The poorer response in New York was probably related to severe drought stress that occurred throughout most of the study.

Researchers in Maryland (Dernoeden and Krouse, 1991) reported that tank-mixes of dithiopyr at $0.28 \mathrm{~kg} \cdot \mathrm{ha}^{-1}$ with quinclorac at 0.28 or $0.56 \mathrm{~kg} \cdot \mathrm{ha}^{-1}$ did not control large crabgrass as effectively as did dithiopyr applied alone at $0.28 \mathrm{~kg} \cdot \mathrm{ha}^{-1}$. The lower weed control was probably related to an antagonistic effect. However, when tank-mixes of dithiopyr at $0.28 \mathrm{~kg} \cdot \mathrm{ha}^{-1}$ and quinclorac at 0.84 $\mathrm{kg} \cdot \mathrm{ha}^{-1}$ were applied to two to three tillered large crabgrass plants, the control varied with turfgrass species in New Jersey (Enache and Ilnicki, 1991). They reported no difference in large crabgrass control in Kentucky bluegrass and perennial ryegrass (Lolium perenne L.) when quinclorac was applied alone at 0.84 $\mathrm{kg} \cdot \mathrm{ha}^{-1}$ or when tank-mixed with dithiopyr at $0.28 \mathrm{~kg} \cdot \mathrm{ha}^{-1}$. However, the tank-mixed treatments controlled large crabgrass better $(85 \%)$ than when quinclorac was applied alone $(73 \%)$ in tall fescue (Festuca arundinacea Schreb.). The difference in weed control between turfgrass species was probably related to tall fescue being more competitive after injury caused by herbicide than Kentucky bluegrass and perennial ryegrass. Therefore, the effectiveness of tank-mixed herbicide treatments depends on herbicides, rate of application, and species involved.

Information is needed on the lowest rates of herbicides needed to maintain consistent weed control in turf. Therefore, two experiments were initiated: a) to determine if reduced rates of preemergence herbicides applied with postemergence herbicides in sequence or tank-mixed would control large crabgrass and goosegrass as effectively as preemergence herbicide applied alone at the full rate and b) the influence of such treatments on Kentucky bluegrass.

\section{Materials and Methods}

Two herbicide experiments were conducted on common Kentucky bluegrass at Butternut Creek Golf Course, Blairsville, Ga., during 1991 and 1992. The experiments were conducted at different sites on the golf course during the 2 years.

Sequential pre- and postgermination application. All preemergence herbicides were applied at one-half of the recommended and at the recommended rates. Oxadiazon (2.2 and $4.5 \mathrm{~kg} \cdot \mathrm{ha}^{-1}$ ), pendimethalin (1.7 and 3.4 $\left.\mathrm{kg} \cdot \mathrm{ha}^{-1}\right)$, and dithiopyr $\left(0.28\right.$ and $\left.0.56 \mathrm{~kg} \cdot \mathrm{ha}^{-1}\right)$ were applied 5 Mar. 1991 and 2 Mar. 1992. Postemergence herbicides fenoxaprop $(0.20$ $\left.\mathrm{kg} \cdot \mathrm{ha}^{-1}\right)$, MSMA (2.2 kg.ha $\left.{ }^{-1}\right)$, and quinclorac $\left(0.84 \mathrm{~kg} \cdot \mathrm{ha}^{-1}\right)$ were applied at recommended rates on 11 June 1991 and 25 June 1992. The postemergence herbicides were applied to plots previously treated with one-half rate of each preemergence herbicide and to nontreated plots. The preemergence herbicides were applied to prevent or reduce weed germination, and postemergence herbicides were applied to control emerged weeds.

Tank-mixed pre- and postgermination application. Recommended rates of postemergence herbicides fenoxaprop $\left(0.20 \mathrm{~kg} \cdot \mathrm{ha}^{-1}\right)$, MSMA (2.2 $\left.\mathrm{kg} \cdot \mathrm{ha}^{-1}\right)$, and quinclorac $(0.84$ $\mathrm{kg} \cdot \mathrm{ha}^{-1}$ ) were applied alone and tank-mixed with one-half recommended rates of the 
preemergence herbicides dithiopyr $(0.28$ $\left.\mathrm{kg} \cdot \mathrm{ha}^{-1}\right)$ and pendimethalin $\left(1.7 \mathrm{~kg} \cdot \mathrm{ha}^{-1}\right)$ on 4 June 1991 and 22 June 1992. A reduced rate of $0.14 \mathrm{~kg} \cdot \mathrm{ha}^{-1}$ was included for fenoxaprop. Dithiopyr at 0.28 and $0.56 \mathrm{~kg} \cdot \mathrm{ha}^{-1}$ and pendimethalin at 1.7 and $3.4 \mathrm{~kg} \cdot \mathrm{ha}^{-1}$ were applied as single treatments. The tank-mixed postemergence herbicides were applied to control emerged weeds, and the preemergence herbicides were applied to prevent additional weed germination.

General procedures. Actively growing Kentucky bluegrass on the golf course fairways was mowed with a reel mower at a height of 3 to $4 \mathrm{~cm}$ once per week and clippings were returned. The turfgrass was not fertilized or irrigated. However, rainfall distribution was favorable, with total rainfall from March through August of 990 and $870 \mathrm{~mm}$ for 1991 and 1992, respectively; drought stress was not evident either year. All herbicides were applied as a broadcast spray with a $\mathrm{CO}_{2}$-pressurized backpack sprayer in 375 liters water/ha.

The soil type was a Hatboro loam (Typic Fluvaquents); it consisted of $41 \%$ sand, 39\% silt, and $20 \%$ clay. The organic matter content was $2.1 \%$. When postemergence treatments were applied, large crabgrass was mostly in the 3-to 5-tiller and goosegrass was mostly in the 1- to 3-tiller growth stages.

Weed populations varied within each experiment when final ratings were made in 1991 and 1992. The weed composition in the sequential preemergence and postemergence herbicide experiment was $92 \%$ large crabgrass in 1991 and 22\% large crabgrass and $43 \%$ goosegrass in 1992. The weed composition in the experiment with tank-mixed preemergence and postemergence herbicides was $18 \%$ goosegrass and $74 \%$ large crabgrass in 1991 and $1 \%$ goosegrass and $84 \%$ large crabgrass in 1992. In several herbicide-treated plots, the population of goosegrass increased significantly from June to August. When this occurred, it was due to elimination of large crabgrass competition when selected herbicides had little or no activity on goosegrass.

Turfgrass injury and weed control were rated visually during 1991 and 1992. Turfgrass injury ratings were made after the postemergence herbicide treatments and were based on 0 to 100 , where $0=$ no injury, 1 to $15=$ minor leaf discoloration, 16 to $30=$ moderate discoloration with some plant necrosis, $>30=$ moderate to severe leaf discoloration and plant necrosis, and $100=$ complete kill. Large crabgrass and goosegrass were rated in late June, July, and August and were based on populations in a nontreated control where $0=$ no control and $100=$ complete control. Acceptable control would be $\geq 80 \%$.

The design was a randomized block with four replications. Plot size was $1.5 \times 3 \mathrm{~m}$. Due to the complexity of the preemergence and postemergence herbicide applications, no attempt was made to implement a factorial experimental layout. With this design, herbicide $\times$ herbicide interactions are not partitioned out of the main effects and can potentially cause problems with correct interpretation of results. Nevertheless, the layout was deemed appropriate for testing the relative merits of preemergence/postemergence herbicide prescriptions. Thus, a one-way analysis of variance (ANOVA) across and within years was performed using the General Linear Models procedure (SAS Institute, 1982). There were herbicide $\times$ year interactions in the sequential preemergence and postemergence experiment, and means are presented separately. There were also herbicide $\times$ year interactions for turf injury on 8 July \pm 13 days and large crabgrass on 30 July \pm 5 days in the tank-mixed preemergence and postemergence experiment, and their means are presented separately. Other variables from the tank-mixed experiment had no herbicide $\times$ year interactions, and their means are averaged across years. All data were analyzed before and after administering the arcsin transformation. There was no practical difference when interpreting results from the two analyses; therefore, the data are presented in the original scale.

\section{Results and Discussion}

Sequential preemergence and postemergence application. There were herbicide $\times$ year interactions for turfgrass injury and large crabgrass control from sequential preemergence and postemergence herbicide treatments in both years (Table 1).

Large crabgrass control. The control of large crabgrass in Kentucky bluegrass turf in late June 1991 was $\geq 88 \%$ for all herbicides except when pendimethalin was applied as preemergence at one-half rate $\left(1.7 \mathrm{~kg} \cdot \mathrm{ha}^{-1}\right)$ $(31 \%)$, dithiopyr applied preemergent at onehalf rate $\left(0.28 \mathrm{~kg} \cdot \mathrm{ha}^{-1}\right)(64 \%)$, and when fenoxaprop was applied postemergent at 0.20 $\mathrm{kg} \cdot \mathrm{ha}^{-1}(71 \%)$ (Table 2). However, the control was $\geq 93 \%$ when fenoxaprop was applied at $0.20 \mathrm{~kg} \cdot \mathrm{ha}^{-1}$ to plots previously treated with pendimethalin at $1.7 \mathrm{~kg} \cdot \mathrm{ha}^{-1}$ and dithiopyr at $0.28 \mathrm{~kg} \cdot \mathrm{ha}^{-1}$. This result indicates that sequential preemergence and postemergence herbicide treatments are needed for consistent large crabgrass control when reduced preemergence herbicide rates are used.

The ability of herbicides to perform consistently throughout the full growing season depends on the herbicides and rates of application. By 20 Aug., large crabgrass control was poor $(\leq 46 \%)$ whether pendimethalin at 1.7 $\mathrm{kg} \cdot \mathrm{ha}^{-1}$, dithiopyr at $0.28 \mathrm{~kg} \cdot \mathrm{ha}^{-1}$, MSMA at $2.2 \mathrm{~kg} \cdot \mathrm{ha}^{-1}$, or fenoxaprop at $0.20 \mathrm{~kg} \cdot \mathrm{ha}^{-1}$ was applied alone or in sequential applications (pendimethalin and dithiopyr applied with either MSMA or fenoxaprop) (Table 2). How- ever, the control was $79 \%$ to $83 \%$ at this date when oxadiazon at $2.2 \mathrm{~kg} \cdot \mathrm{ha}^{-1}$ was applied in sequence with MSMA or fenoxaprop. The control from sequential applications was higher than when either herbicide was applied alone at the same rate [oxadiazon (62\%), MSMA $(37 \%)$, and fenoxaprop (11\%)]. Oxadiazon evaluated as a single application at the recommended rate $\left(4.5 \mathrm{~kg} \cdot \mathrm{ha}^{-1}\right)$ during this period in 1991 resulted in excellent large crabgrass control $(91 \%)$, while the control was poor $(\leq 42 \%)$ from the recommended rates for pendimethalin $\left(3.4 \mathrm{~kg} \cdot \mathrm{ha}^{-1}\right)$ and dithiopyr $\left(0.56 \mathrm{~kg} \cdot \mathrm{ha}^{-1}\right)$. Large crabgrass control from the full oxadiazon rate was equal to or higher in all instances than that obtained from any other treatment. These results indicate that herbicides will not always provide consistent weed control when applied at recommended rates.

Large crabgrass control was higher when quinclorac was applied alone at $0.84 \mathrm{~kg} \cdot \mathrm{ha}^{-1}$ $(88 \%)$ than when MSMA $(37 \%)$ and fenoxaprop $(11 \%)$ were applied alone for ratings made on 20 Aug. 1991 (Table 2). There was no advantage from sequential applications of quinclorac with reduced rates of oxadiazon (94\%), pendimethalin $(89 \%)$, and dithiopyr (94\%), when compared with quinclorac alone $(88 \%)$.

All herbicide treatments controlled $\geq 75 \%$ large crabgrass on 31 Aug. 1992 (Table 2) whether the preemergence or postemergence herbicides were applied alone or as sequential applications. The difference in large crabgrass control between years was probably related to time of postemergence application and weed population. Postemergence herbicides were applied on 22 June 1992, which was 11 days later than 1991. Since June is the optimum time for large crabgrass growth at this location, a few days later in postemergence treatments can make a difference in weed size and herbicide performance. Goosegrass that was present during 1992 competed with emergence and growth of large crabgrass during the summer.

Although a difference in large crabgrass control followed application of preemergence herbicides, the control was generally the same when a given preemergence herbicide was applied at the recommended rate, or when applied at one-half the recommended rate and followed by postemergence herbicide MSMA or fenoxaprop. In an earlier study, Johnson (1993) reported that preemergence herbicides applied at one-half recommended rate at times controlled large crabgrass without the postemergence treatments. Therefore, a pro-

Table 1. Analysis of variance for sequential preemergence and postemergence herbicides on injury and control of large crabgrass and goosegrass in Kentucky bluegrass turf at Blairsville, Ga.

\begin{tabular}{|c|c|c|c|c|}
\hline \multirow[b]{3}{*}{ Source } & \multicolumn{4}{|c|}{$P>\mathrm{F}$} \\
\hline & \multirow{2}{*}{$\frac{\text { Turf injury }}{1 \text { July } \pm 5 \text { days }}$} & \multicolumn{2}{|c|}{ Large crabgrass control } & \multirow{2}{*}{$\frac{\text { Goosegrass control }}{31 \text { Aug. }^{2}}$} \\
\hline & & 1 July \pm 5 days & 26 Aug. \pm 5 days & \\
\hline$\overline{\operatorname{Rep}}$ & 0.1005 & 0.9473 & 0.0095 & 0.0003 \\
\hline Year $(Y R)^{y}$ & 0.4300 & 0.0729 & 0.0063 & --- \\
\hline $\operatorname{Rep} \times \mathrm{YR}($ error A) & 0.0002 & 0.2978 & 0.0057 & --- \\
\hline Treatment (TRT) & 0.0001 & 0.0001 & 0.0001 & 0.0001 \\
\hline $\mathrm{YR} \times \mathrm{TRT}$ & 0.0001 & 0.0001 & 0.0001 & --- \\
\hline
\end{tabular}

${ }^{\mathrm{z} N o}$ data collected for 1991 .

${ }^{y}$ YR effect tested in 1991 and 1992 using Rep $\times$ YR (error A) as the error term. 
Table 2. Effects of sequential preemergence and postemergence herbicides on injury and control of large crabgrass and goosegrass in Kentucky bluegrass turf at Blairsville, Ga.

\begin{tabular}{|c|c|c|c|c|c|c|c|c|c|}
\hline & & & & \multicolumn{4}{|c|}{ Weed control ${ }^{\mathrm{z}}$} & & \\
\hline & & & & \multicolumn{3}{|c|}{ Large crabgrass } & \multirow{4}{*}{$\frac{\frac{\text { Goosegrass }}{1992}}{\frac{31 \mathrm{Aug} .}{\%}}$} & \multicolumn{2}{|c|}{ Turf injury ${ }^{y}$} \\
\hline \multicolumn{4}{|c|}{ Treatments $^{\mathrm{x}}$} & \multicolumn{2}{|c|}{1991} & \multirow{3}{*}{$\frac{1992}{31 \mathrm{Aug}}$} & & \multirow{2}{*}{$\frac{1991}{25 \text { June }}$} & \multirow{2}{*}{$\frac{1992}{6 \text { July }}$} \\
\hline \multirow[b]{2}{*}{ Preemergence } & \multirow{2}{*}{$\begin{array}{c}\text { Rate } \\
\left(\mathrm{kg}^{2} \mathrm{ha}^{-1}\right)\end{array}$} & \multirow[b]{2}{*}{ Postemergence } & \multirow{2}{*}{$\begin{array}{c}\text { Rate } \\
\left(\mathrm{kg}^{2} \mathrm{ha}^{-1}\right)\end{array}$} & 25 June & $20 \mathrm{Aug}$. & & & & \\
\hline & & & & \multicolumn{2}{|r|}{$\%$} & & & \multicolumn{2}{|c|}{$\%$} \\
\hline Nontreated & --- & --- & --- & 0 & 0 & 0 & 0 & 0 & 0 \\
\hline \multirow[t]{2}{*}{ Oxadiazon } & 4.5 & --- & --- & 100 & 91 & 93 & 74 & 4 & 12 \\
\hline & 2.2 & --- & --- & 88 & 62 & 78 & 69 & 4 & 2 \\
\hline \multirow[t]{2}{*}{ Pendimethalin } & 3.4 & --- & --- & 88 & 29 & 79 & 41 & 0 & 25 \\
\hline & 1.7 & --- & --- & 31 & 9 & 78 & 38 & 3 & 20 \\
\hline \multirow[t]{2}{*}{ Dithiopyr } & 0.56 & --- & --- & 93 & 42 & 98 & 63 & 0 & 16 \\
\hline & 0.28 & --- & --- & 64 & 19 & 75 & 43 & 4 & 5 \\
\hline --- & --- & Fenoxaprop & 0.20 & 71 & 11 & 94 & 0 & 7 & 25 \\
\hline--- & --- & MSMA & 2.2 & 99 & 37 & 93 & 9 & 61 & 56 \\
\hline--- & --- & Quinclorac & 0.84 & 99 & 88 & 94 & 28 & 51 & 22 \\
\hline \multirow[t]{3}{*}{ Oxadiazon } & 2.2 & Fenoxaprop & 0.20 & 99 & 83 & 93 & 39 & 9 & 20 \\
\hline & 2.2 & MSMA & 2.2 & 98 & 79 & 79 & 44 & 50 & 54 \\
\hline & 2.2 & Quinclorac & 0.84 & 100 & 94 & 92 & 51 & 26 & 31 \\
\hline \multirow[t]{3}{*}{ Pendimethalin } & 1.7 & Fenoxaprop & 0.20 & 98 & 46 & 97 & 10 & 4 & 19 \\
\hline & 1.7 & MSMA & 2.2 & 94 & 41 & 88 & 45 & 57 & 31 \\
\hline & 1.7 & Quinclorac & 0.84 & 99 & 89 & 86 & 23 & 53 & 35 \\
\hline \multirow[t]{3}{*}{ Dithiopyr } & 0.28 & Fenoxaprop & 0.20 & 93 & 21 & 95 & 38 & 10 & 23 \\
\hline & 0.28 & MSMA & 2.2 & 96 & 23 & 96 & 26 & 38 & 42 \\
\hline & 0.28 & Quinclorac & 0.84 & 99 & 94 & 98 & 26 & 39 & 25 \\
\hline $\operatorname{LSD}_{0.05}{ }^{\mathrm{w}}$ & & & & 19 & 16 & 14 & 26 & 15 & 19 \\
\hline
\end{tabular}

${ }^{\mathrm{z}}$ Weed control ratings were based on $0=$ no control and $100=$ complete control.

yTurfgrass injury ratings were made 1 to 2 weeks after treatment and based on $0=$ no injury and $100=$ complete kill.

xPreemergence herbicides were applied 5 Mar. 1991 and 2 Mar. 1992, and postemergence herbicides were applied 11 June 1991 and 22 June 1992.

"Means were separated using Fisher's protected LSD procedure.

gram using lower rates of preemergence herbicides can be used by a turf manager. If the lower rates do not provide full-season control, postemergence herbicides can be applied during late spring or summer to extend the weed control period.

Goosegrass control. None of the herbicides had controlled goosegrass effectively ( $\geq 80 \%$ ) when ratings were made 31 Aug. 1992 (Table 2). The control was $74 \%$ in plots treated with oxadiazon at $4.5 \mathrm{~kg} \cdot \mathrm{ha}^{-1}$, but $<70 \%$ was obtained when treated with any other herbicide applied alone or with postemergence herbicides. The postemergence herbicides fenoxaprop, MSMA, and quinclorac had little or no activity on goosegrass.

Turfgrass injury. Kentucky bluegrass inwhen ratings were made 2 WAT on 25 June 1991 and 6 July 1992 (Table 2). The initial injury was higher in plots treated with MSMA at $2.2 \mathrm{~kg} \cdot \mathrm{ha}^{-1}$ than in plots treated with fenoxaprop at $0.20 \mathrm{~kg} \cdot \mathrm{ha}^{-1}$ both years. Turf treated with quinclorac was injured similarly to that treated with MSMA in 1991, but less than when treated with MSMA in 1992. Turfgrass injury from postemergence herbicides was similar when the postemergence treatments were applied alone or to plots previously treated with preemergence herbicides.

There was no difference in injury of Kentucky bluegrass from herbicide treatments when ratings were made in late Aug. 1991 and 1992 (data not given). This result indicates that the turf fully recovered from injury caused by postemergence herbicides.

Tank-mixed preemergence and postemergence application. Herbicide $\times$ year interactions for turfgrass injury and large crabgrass control ratings were made 30 July \pm 5 days jury varied with postemergence herbicides following tank-mixed preemergence and postemergence application of herbicides during 1991 and 1992 (Table 3). All other data are reported for the 2 years combined. plied at $0.84 \mathrm{~kg} \cdot \mathrm{ha}^{-1}$ resulted in excellent large crabgrass control throughout the summer whether applied alone $(\geq 97 \%)$ or with reduced rates of pendimethalin $(\geq 97 \%)$ and dithiopyr $(\geq 94 \%$ ) (Table 4). This finding indicates that quinclorac had full-season activity on large crabgrass; thus, no preemergence herbicides would be needed. MSMA applied at 2.2 $\mathrm{kg} \cdot \mathrm{ha}^{-1}$ had controlled large crabgrass as effectively by 24 July 1991 and 4 Aug. 1992 as when applied with pendimethalin or dithiopyr. However, by late August, the control was higher when MSMA was applied with the preemergence herbicides ( $92 \%$ to $98 \%$ ) than from MSMA $(77 \%)$, pendimethalin $(\leq 28 \%)$, or dithiopyr at $0.28 \mathrm{~kg} \cdot \mathrm{ha}^{-1}$ alone $(81 \%)$. Therefore, MSMA required the addition of preemergence herbicides to maintain full-season large crabgrass control, while quinclorac did not.

Fenoxaprop applied alone at $0.14 \mathrm{~kg} \cdot \mathrm{ha}^{-1}$ resulted in $73 \%$ control of large crabgrass

Table 3. Analysis of variance for tank-mixed preemergence and postemergence herbicides on injury and control of large crabgrass and goosegrass in Kentucky bluegrass turf at Blairsville, Ga.

\begin{tabular}{|c|c|c|c|c|c|}
\hline \multirow[b]{3}{*}{ Source } & \multicolumn{5}{|c|}{$P>\mathrm{F}$} \\
\hline & \multicolumn{2}{|c|}{ Turf injury } & \multicolumn{2}{|c|}{ Large crabgrass control } & \multirow{2}{*}{$\frac{\text { Goosegrass contro }}{27 \text { Aug. } \pm 5 \text { days }}$} \\
\hline & 8 July \pm 13 days & 30 July \pm 5 days & 30 July \pm 5 days & 27 Aug. \pm 5 days & \\
\hline$\overline{\operatorname{Rep}}$ & 0.5884 & 0.0002 & 0.1304 & 0.3218 & 0.0518 \\
\hline Year $(Y R)^{\mathrm{z}}$ & 0.0199 & 0.0434 & 0.2274 & 0.3433 & 0.2829 \\
\hline $\begin{array}{l}\text { Rep } \times \text { YR } \\
(\text { error A) }\end{array}$ & 0.0136 & 0.0018 & 0.0045 & 0.0056 & 0.4302 \\
\hline $\begin{array}{l}\text { Treatment } \\
(\mathrm{TRT}) \\
\mathrm{YR} \times \mathrm{TRT}\end{array}$ & $\begin{array}{l}0.0001 \\
0.2372\end{array}$ & $\begin{array}{l}0.0001 \\
0.0190\end{array}$ & $\begin{array}{l}0.0001 \\
0.0165\end{array}$ & $\begin{array}{l}0.0001 \\
0.1195\end{array}$ & $\begin{array}{l}0.0001 \\
0.8748\end{array}$ \\
\hline
\end{tabular}

${ }^{2}$ YR effect tested using Rep $\times$ YR (error A) as the error term.

when ratings were made on 24 July 1991 (Table 4). However, the control on 4 Aug. 1992 was poor (44\%). The poor control in 1992 was probably related to weed size at treatment. Since herbicide treatments in 1992 were made 18 days later than in 1991, it is likely that crabgrass seedlings were larger, and fenoxaprop at $0.14 \mathrm{~kg} \cdot \mathrm{ha}^{-1}$ had poor activity on tillered large crabgrass seedlings. When the rate used was $0.20 \mathrm{~kg} \cdot \mathrm{ha}^{-1}$, the control was $75 \%$ on 24 July 1991 and $73 \%$ on 4 Aug. 1992, but only $67 \%$ by late August. Therefore, the activity of fenoxaprop on large crabgrass was limited regardless of rate, and full-season weed control was not obtained. However, when fenoxaprop at $0.14 \mathrm{~kg} \cdot \mathrm{ha}^{-1}$ was tank-mixed with reduced pendimethalin at $1.7 \mathrm{~kg} \cdot \mathrm{ha}^{-1}$, the control on 27 Aug. was higher (80\%) than when either fenoxaprop $(55 \%)$ or pendimethalin $(28 \%)$ was applied alone. A similar response was noted from tank-mixes of fenoxaprop $\left(0.14 \mathrm{~kg} \cdot \mathrm{ha}^{-1}\right)$ with dithiopyr $\left(0.28 \cdot \mathrm{kg} \mathrm{ha}^{-1}\right)$. Large crabgrass control did not improve when the rate of fenoxaprop was 0.20 $\mathrm{kg} \cdot h \mathrm{~h}^{-1}$ rather than $0.14 \mathrm{~kg} \cdot \mathrm{ha}^{-1}$ and tank-mixed with the preemergence herbicides. These re-
Large crabgrass control. Quinclorac ap- 
Table 4. Effects of tank-mixed preemergence and postemergence herbicides on injury and control of large crabgrass and goosegrass in Kentucky bluegrass turf at Blairsville, Ga.

\begin{tabular}{|c|c|c|c|c|c|c|c|c|}
\hline \multirow{3}{*}{\multicolumn{2}{|c|}{ Treatments }} & \multicolumn{4}{|c|}{ Weed control $^{2}$} & & & \\
\hline & & \multicolumn{3}{|c|}{ Large crabgrass } & \multirow{3}{*}{$\begin{array}{c}\frac{\text { Goosegrass control }}{\text { Mean } 2 \text { year }} \\
27 \text { Aug. } \\
\end{array}$} & \multicolumn{3}{|c|}{ Turfgrass injury } \\
\hline & & 1991 & 1992 & Mean 2 year & & 1991 & 1992 & Mean 2 year \\
\hline \multirow[b]{2}{*}{ Herbicide $^{x}$} & \multirow{2}{*}{$\begin{array}{c}\text { Rate } \\
\left(\mathrm{kg} \cdot \mathrm{ha}^{-1}\right)\end{array}$} & 24 July & 4 Aug. & 27 Aug. & & 25 June & 20 July & 30 July \\
\hline & & & $\%$ & & $\%$ cover & & $\%$ & \\
\hline Nontreated & $\begin{array}{ll}-- \\
\end{array}$ & 0 & 0 & 0 & 9 & 0 & 0 & 0 \\
\hline \multirow[t]{2}{*}{ Fenoxaprop } & 0.14 & 73 & 44 & 55 & 39 & 14 & 36 & 19 \\
\hline & 0.20 & 75 & 73 & 67 & 44 & 20 & 33 & 17 \\
\hline Quinclorac & 0.84 & 97 & 100 & 97 & 47 & 23 & 41 & 35 \\
\hline MSMA & 2.2 & 83 & 97 & 77 & 43 & 38 & 55 & 34 \\
\hline \multirow{2}{*}{ Dithiopyr } & 0.28 & 89 & 85 & 81 & 28 & 5 & 24 & 25 \\
\hline & 0.56 & 99 & 88 & 88 & 34 & 13 & 27 & 22 \\
\hline \multirow[t]{2}{*}{ Pendimethalin } & 1.7 & 48 & 56 & 28 & 11 & 6 & 12 & 13 \\
\hline & 3.4 & 36 & 52 & 24 & 10 & 0 & 18 & 15 \\
\hline \multicolumn{9}{|l|}{ Pendimethalin } \\
\hline \multirow[t]{2}{*}{+ fenoxaprop } & $1.7+0.14$ & 78 & 99 & 80 & 23 & 12 & 24 & 20 \\
\hline & $1.7+0.20$ & 76 & 93 & 79 & 19 & 11 & 24 & 23 \\
\hline \multicolumn{9}{|l|}{ Pendimethalin } \\
\hline \multicolumn{9}{|l|}{ Pendimethalin } \\
\hline + MSMA & $1.7+2.2$ & 95 & 96 & 92 & 26 & 43 & 70 & 46 \\
\hline \multicolumn{9}{|l|}{ Dithiopyr } \\
\hline \multirow[t]{2}{*}{ + fenoxaprop } & $0.28+0.14$ & 96 & 98 & 98 & 16 & 15 & 30 & 28 \\
\hline & $0.28+0.20$ & 94 & 100 & 99 & 26 & 19 & 36 & 26 \\
\hline \multicolumn{9}{|l|}{ Dithiopyr } \\
\hline + quinclorac & $0.28+0.84$ & 94 & 100 & 98 & 57 & 28 & 63 & 27 \\
\hline \multicolumn{9}{|l|}{ Dithiopyr } \\
\hline + MSMA & $0.28+2.2$ & 96 & 100 & 98 & 33 & 31 & 77 & 62 \\
\hline $\mathrm{LSD}_{0.05}{ }^{\mathrm{w}}$ & & 21 & 17 & 14 & 22 & 18 & 23 & 18 \\
\hline
\end{tabular}

${ }^{\mathrm{z}}$ Herbicides were applied as a single application 4 June 1991 and 22 June 1992.

yTurfgrass injury ratings were based on $0=$ no injury and $100=$ complete kill. The mean ratings were made \pm 1 week within the given date.

${ }^{x}$ Large crabgrass control ratings were based on $0=$ no control and $100=$ complete control; goosegrass control ratings were based on percent cover, where $0=$ complete control. The mean ratings were made \pm 1 week within the given date.

"Means were separated using Fisher's protected LSD procedure.

sults were similar to those reported in Arkansas (King, 1990), New York (Rossi et al., 1988), and Pennsylvania (Watschke and Hamilton, 1990).

These results indicate that consistently higher large crabgrass control was obtained from tank-mixes of fenoxaprop or MSMA with reduced rates of pendimethalin and dithiopyr than when either herbicide was applied alone. Quinclorac applied alone controlled large crabgrass as effectively as it did when tank-mixed with the preemergence herbicides.

Goosegrass control. None of the postemergence herbicides applied alone or tank-mixed with preemergence herbicides had controlled emerged goosegrass effectively by late $\mathrm{Au}$ gust (Table 4). Increasing preemergence rates when tank-mixing with the postemergence herbicides were not beneficial. The poor goosegrass control was related to the poor initial control by postemergence herbicides.

Turfgrass injury. MSMA severely injured (38\%) Kentucky bluegrass turf when ratings were made 3 WAT on 25 June 1991 (Table 4). The injury ranged from $14 \%$ to $23 \%$ when treated with fenoxaprop and quinclorac during the same period. However, the injury was $\geq 33 \%$ from all postemergence herbicides when ratings were made at 4 WAT on July 1992. Turf treated with MSMA and quinclorac recovered slightly by 30 July, but the injury was higher $(\geq 34 \%)$ than most turf managers would accept. The observed injury from the postemergence treatments alone was similar to that obtained in the sequential preemergence and postemergence experiment (Table 2).

By 30 July, turfgrass injury was higher when MSMA at $2.2 \mathrm{~kg} \cdot \mathrm{ha}^{-1}$ was tank-mixed with dithiopyr $\left(0.28 \mathrm{~kg} \cdot \mathrm{ha}^{-1}\right)(62 \%)$ than when either herbicide was applied alone $(25 \%$ to $34 \%$ ) (Table 4). The amount of injury from the MSMA and pendimethalin combination was $46 \%$, but it was not significantly higher than turf treated with MSMA alone. Turfgrass treated with combinations of fenoxaprop or quinclorac with preemergence herbicides did not injure the turf any higher, when compared with postemergence herbicides alone.

Tank-mixes of fenoxaprop or MSMA with pendimethalin and dithiopyr herbicides applied after weeds emerge in the spring may offer an advantage in controlling large crabgrass in turf. Because postemergence herbicides do not have residual activity and multiple applications are usually needed to maintain effective weed control, tank-mixing with preemergent herbicides at reduced rates would be beneficial. A disadvantage is that tankmixes of the postemergence herbicides MSMA, fenoxaprop, or quinclorac with pendimethalin and dithiopyr do not adequately control goosegrass (Johnson and Murphy, 1993).

\section{Literature Cited}

Chism, W.J. and S.W. Bingham. 1991. Postemergence control of large crabgrass (Digitaria sanguinalis) with herbicides. Weed Sci. 39:6266.
Dernoeden, P.H. and D.B. Davis. 1988. Smooth crabgrass control with pre- and postemergence herbicides. 1987. Proc. Northeastern Weed Sci. Soc. 42:161-162.

Dernoeden, P.H. and J.M. Krouse. 1991. Selected crabgrass control evaluations for Maryland in 1990. Proc. Northeastern Weed Sci. Soc. 45:117 118.

Enache, A.J. and R.D. Ilnicki. 1991. BAS 514 and dithiopyr for weed control in cool-season turfgrasses. Weed Technol. 5:616-621.

Green, J.M. 1991. Maximizing herbicide efficiency with mixtures and expert systems. Weed Technol. 5:894-897.

Johnson, B.J. 1975. Postemergence control of large crabgrass and goosegrass in turf. Weed Sci. 23:404-409.

Johnson, B.J. 1980. Goosegrass (Eleusine indica) control in bermudagrass (Cynodon dactylon) turf. Weed Sci. 28:378-381.

Johnson, B.J. 1993. Sequential herbicide treatments for crabgrass (Digitaria sanguinalis) and goosegrass (Eleusine indica) control in bermudagrass (Cynodon dactylon) turf. Weed Technol. 7:674-680.

Johnson, B.J. and T.R. Murphy. 1993. Summer weed control with herbicides in turf-grasses. Georgia Agr. Res. Bul. 411.

King, J.W. 1990. Fenoxaprop for crabgrass and goosegrass control in turfgrasses. Ark. Farm Res. 39(2):7.

Rossi, F.S., J.C. Neal, and A.F. Senesac. 1988 Tank-mixing with preemergence materials to enhance fenoxaprop efficacy. Proc. Northeastern Weed Sci. Soc. 42:150-154.

Watschke, T.L. and G.W. Hamilton. 1990. Pre-post combinations for weed control in turf. Proc. Northeastern Weed Sci. Soc. 44:138-139. 